\title{
APLIKASI DESIGN OF EXPERIMENT DALAM PROSES OPTIMASI MOISTURE CONTENT PADA PENGERINGAN KAYU MENGGUNAKAN KILN DRYING
}

\author{
Sukirman \\ Jurusan Teknik Kimia, Fakultas Teknologi Industri, Universitas Islam Indonesia \\ email:skmtekuii_85@yahoo.com
}

\begin{abstract}
The utilization of wood for furniture industry require special handling such as reduction of the content of water in order to produce a quality product. Drying the means used to reduce the water content results in a timber. The purpose of this is to predict the value pebelitian water content (moisture content) on the wood drying kiln wood drying process. This prediction is required to determine the quality of the wood to be processed as well about half finished products and finished products.

Besides the impact on the moisture content of wood durability. Thus the current drying in an oven (kiln) required proper variable settings. Design of Experiment (DOE) can be used to predict the exact value of moisture content and quickly with low cost. In this study, the values obtained optimum moisture content $17.3 \%$, with the optimum factor levels for temperature $=50^{\circ} \mathrm{C}$, the cross-sectional area $=415 \mathrm{~cm} 2$ object, relative humidity $=80 \%$, time $=15$ days. Improved performance is achieved up to $12: 57 \%$ compared with the previous arrangement.
\end{abstract}

Keywords: moisture content, wood drying kilns, design of experiments.

\section{PENDAHULUAN}

Sering dikeluhkan oleh konsumen kepada perusahaan furniture karena setelah produk dibeli sering terjadi perubahan bentuk. Perubahan dimensi dan bentuk ini pada saat telah menjadi produk disebabkan karena menyusutnya kandungan air didalam bahan kayu tersebut. Pada saat kayu akan digunakan sebagai bahan produksi proses sebelumnya (pengeringan) kurang optimal. Kayu masih memiliki kadar air yang tinggi. Hal ini disebabkan karena pengeringan kayu yang dilakukan di Industri Kayu Mentah (IKM) menggunakan proses tradisional (alami). Proses pengeringan yang biasa digunakan biasanya menggunakan sinar matahari, sementara untuk mengeringkan kadar air dalam kayu relatif sukar untuk diatur, sehingga bahan kayu untuk produksi yang diperoleh kurang memenuhi persyaratan yang telah ditentukan baik untuk konsumsi dalam maupun luar negeri.

Pengaturan parameter yang merupakan variabel sebelum proses pengeringan perlu dilakukan sebaik mungkin. Hal ini dimaksudkan supaya memperoleh moisture content yang lebih baik. (Lin, 1994) menyatakan bahwa pendekatan dengan ekperimen dapat dilakukan untuk mencapai kondisi permesinan yang optimal, terutama dalam pemprosesan. Namun demikian dari kebiasaan yang dilakukan untuk melakukan identifikasi proses pengeringan optimal akan menghabiskan waktu dan biaya yang mahal.

Vairis, A. dan Petousis, M., (2009) menyatakan bahwa metode design of eksperimen (DOE) telah menjadi suatu metodologi penting yang dapat memaksimalkan data dari eksperimen dengan menggunakan posisi cerdas titik dalam ruang. Metodologi ini menyediakan alat kuat untuk mendesain dan menganalisis percobaan. Disamping itu menghilangkan pengamatan berlebihan dan mengurangi waktu dan sumber daya untuk melakukan percobaan. Pendekatan ini telah terbukti mampu untuk memilih parameter dari proses manufaktur yang dapat menghasilkan kualitas produk yang lebih baik dengan biaya dan waktu yang minimum (Sumarno, 2007). Dalam penelitian ini nilai optimum factor - faktor yang berpengaruh terhadap moisture content pada proses pengeringan menggunakan oven (kiln dryer) diprediksi 
sedemikian dengan menggunakan DOE Taguchi. Kemudian dilakukan perbandinganhasil dengan cara yang digunakan sebelumnya.

\section{KAJIAN LITERATUR}

Pengeringan kayu adalah proses untuk mengeluarkan air yang terdapat di dalam kayu. Kadar air kayu memberikan pengaruh yang sangat besar dalam pemakaian kayu. Untuk berbagai macam dan kegunaan dengan kondisi udara tertentu kayu memerlukan batas kandungan kadar air. Oleh karena itu masalah pengeringan kayu merupakan faktor yang penting untuk dilakukan. Pengeringan kayu memberikan keuntungan seperti (Dumanau, 1993) :

a. Menjamin kesetabilan dimensi kayu. Karena di bawah titik jenuh serat, perubahan kadar air dapat mengakibatkan kembang susut pada kayu. Sebalik jika kayu dikeringkan mendekati kadar air lingkungan, maka sifat kembang susut ini akan dapat teratasi, bahkan dapat di abaikan.

b. Menambah kekuatan kayu. Makin rendah kadar air kayu yang di kandung, maka akan semakin kuat kayu tersebut.

c. Membuat kayu lebih ringan. Dengan demikian ongkos angkutan berkurang.

d. Mencegah serangan jamur dan bubuk kayu. Sebab umumnya jasad renik pengrusak kayu atau jamur tidak dapat hidup di bawah persentase kadar air \pm $20 \%$.

e. Memudahkan pengerjaan selanjutnya. Antara lain yaitu pengetaman, pengrekatan, finishing, pengawetan serta proses-proses kelanjutan lainnya.

\subsection{Kadar Air Kayu (Moisture Content)}

Kayu mempunyai sifat absorbsi, yaitu mampu menyerap udara basah, sebaliknya apabila udara kering, uap air dapat dilepaskan oleh kayu maka kayu menjadi kering. Banyaknya air yang dikandung oleh sepotong kayu disebut dengan kadar air kayu (MC). Jumlah MC tergantung kepada kelembaban udara disekelilingnya dan sangat bervariasi. Rata - rata kayu berkandungan air 6\% - 300\%, dan dinyatakan dalam persentase dari kayu kering tanur.

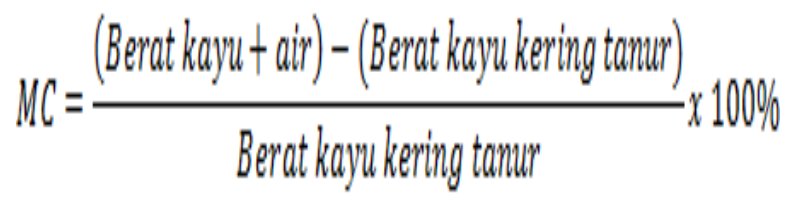

Yang dimaksud dengan kering tanur adalah bahan kayu yang telah dikeringkan didalam alat pengering dan biasanya berkapasitas besar (Rhodes, Daniel, 1968).

Faktor - faktor yang mempengaruhi moisture content adalah temperatur, kelembaban relatif, luas penampang obyek, dan waktu. Jika kelembaban udara tetap dan temperatur naik akan memberikan peningkatan kecepatan penguapan sehingga akan mempercepat pengeringan kayu. Sebaliknya jika apabila temparatur tetap maka penurunan kelembaban udara disekitar kayu akan mempercepat pengeringan kayu. Sehingga yang paling menentukan kecepatan pengeringan adalah temperatur dan kelembaban udara hal ini hanya bisa berjalan apabila terdapat aliran udara melalui permukaan kayu yang mengganti kedudukan udara yang basah dan dingin karena penguapan dengan udara yang kering dan panas. Sehingga luas penampang objek sangat mennetukan jumlah air yang harus dikeringkan. Disamping itu waktu pengeringan akan menentukan volume air yang dikeringkan (William T. Simpson, 1991)

\section{DESIGN OF EXPERIMENTS (DOE)}

Desain eksperimen adalah perancangan percobaan dengan membuat perubahanperubahan pada variabel masukan dari sebuah proses disertai pembahasan analisis statistika, agar kita dapat mengamati dan mengidentifikasi perubahan yang terjadi pada keluaran dari proses tersebut. Tujuan desain eksperimen adalah untuk memperoleh atau mengumpulkan informasi sebanyak banyaknya yang berguna dalam melakukan 
penyelidikan persoalan yang akan dibahas. Fowlkes, Y. W dan Creveling, M. C. (1995), menyatakan bahwa perancangan yang baik harus bersifat :

1. Efektif yaitu kemampuan dalam mencapai tujuan, sasaran dan kegunaan yang digariskan.

2. Terkelola yaitu berkenaan dengan kenyataan adanya berbagai keterbatasan atau kendala yang terdapat dalam pelaksanaan percobaan maupun analisis data.

3. Efisien yaitu berkenaan dengan dana, sumberdaya dan waktu.

4. Dapat dipantau, dikendalikan dan dievaluasi.

Disamping itu terdapat hal - hal yang harus disamakan persepsinya terlebih dahulu dalam DOE, diantaranya :

(a).Perlakuan atau treatment. Sekumpulan kondisi percobaan yang akan dikenakan terhadap unit percobaan dalam ruang lingkup perancangan yang dipilih. Perlakuan ini bisa berbentuk tunggal atau terjadi dalam bentuk kombinasi, misalnya penyelidikan tentang pengaruh jenis makanan terhadap sapi, maka perlakuan bisa berbentuk: jenis sapi, jenis kelamin sapi, umur sapi, atau takaran makanan yang diberikan kepada sapi. Tiap perlakuan di atas merupakan perlakuan tunggal yang mungkin memberikan efek sendiri - sendiri terhadap variabel respon.

(b). Unit percobaanSesuatu yang dikenai oleh perlakuan baik itu berupa perlakuan tunggal atau merupakan gabungan dari beberapa perlakuan.

(c). Kekeliruan percobaan. Kekeliruan percobaan menyatakan kegagalan dari pada dua unit percobaan identik yang dikenai perlakuan untuk memberikan hasil yang sama. Tentu saja kekeliruan ini hendaknya diusahakan supaya terjadi sekecil - kecilnya.

(d). Faktor adalah suatu variabel yang dengan sengaja dikontrol pada suatu eksperimen untuk melihat dampak pada variable respon

(e). Level yaitu nilai yang ditentukan / setting tertentu untuk faktor kuantitatif atau pilihan tertentu untuk faktor kualitatif

\subsection{Prinsip Dasar Desain Eksperimen}

Untuk mengaplikasikan DOE dalam sebuah penelitian maka perlu meperhatikan prinsip - prinsip dasar seperti :

(1). Replikasi adalah pengulangan kembali perlakuan yang sama dalam suatu percobaan dengan kondisi yang sama untuk memperoleh ketelitian yang lebih tinggi.

(2) Pengacakan atau Randomisasi. Secara umum randomisasi dimaksudkan untuk pertama, meratakan pengaruh dari faktorfaktor yang tidak dapat dikendalikan pada semua unit percobaan. Kedua, Memberikan kesempatan yang sama pada setiap unit percobaan untuk menerima suatu perlakuan sehingga diharapkan ada kehomogenan pengaruh dari setiap perlakuan yang sama. Ketiga, mendapatkan hasil pengamatan yang bebas (independent) satu sama lain.

(3) Kontrol lokal atau Blocking. Kontrol lokal menyebabkan percobaan lebih efisien, yaitu menghasilkan prosedur pengujian dengan kuasa yang lebih tinggi. Pemblokan berarti pengalokasian unit - unit percobaan ke dalam blok sedemikian sehingga unit-unit dalam blok secara relatif bersifat homogen sedangkan sebagian besar daripada variasi yang dapat diperkirakan diantara unit - unit telah baur dengan blok.

\subsection{Kontribusi Terhadap Kualitas :}

\subsubsection{The Loss Function}

Konsep Loss Function didasarkan pada total simpangan dari karakteristik kualitas yang ditargetkan. Pada simpangan nol, maka produk tepat sekali seperti apa yang ditargetkan, dan kerugian sama dengan nol. Tujuan dan fungsi kerugian Taguchi adalah untuk mengevaluasi kerugian kualitas secara kuantitatif yang disebabkan adanya variasi. 


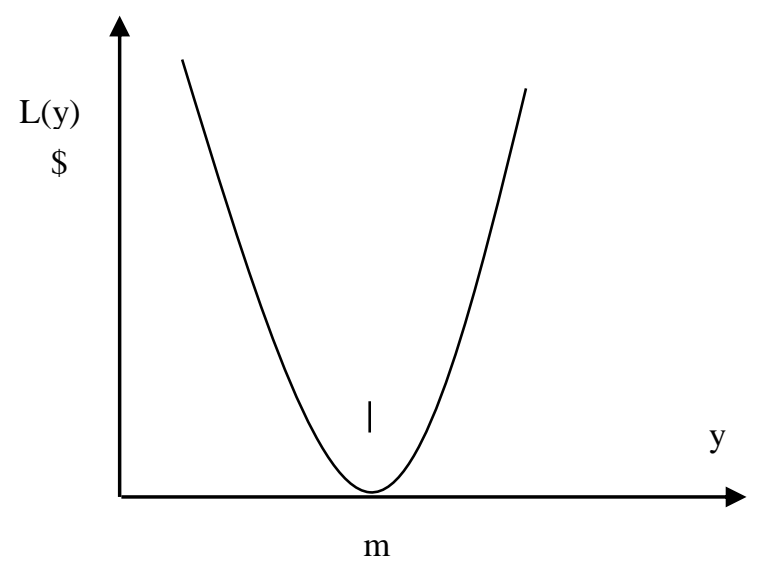

Untuk 1 produk :

$$
\begin{aligned}
& \mathrm{L}(\mathrm{y}) \quad=\mathrm{k}(\mathrm{y}-\mathrm{m})^{2} \\
& \mathrm{Untuk} \text { sample }: \\
& \mathrm{L}(\mathrm{y}) \quad=\mathrm{k}\left[\sigma^{2}+(\mathrm{y}-\mathrm{m})^{2}\right] \\
& \mathrm{K} \quad=\text { konstanta } \\
& \mathrm{Y}=\text { aktual measurement } \\
& \mathrm{m}=\text { nominal target }
\end{aligned}
$$

Gambar 1. Grafik Fungsi Quadratic Loss Nominal the best.

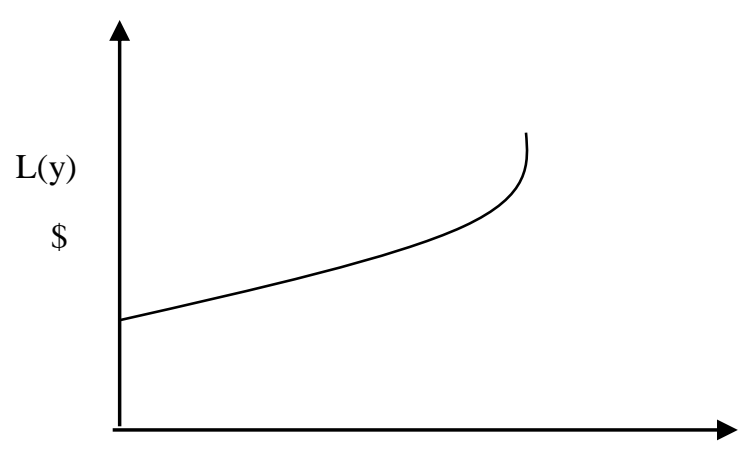

Untuk 1 produk:

$$
\begin{aligned}
& \mathrm{L}(\mathrm{y}) \quad=\mathrm{k}(\mathrm{y}-\mathrm{m})^{2} \ldots . \mathrm{m}=0 \\
& \mathrm{Untuk} \text { simple } \\
& \mathrm{L}(\mathrm{y}) \quad=\mathrm{k}\left[\sigma^{2}+(\mathrm{y})^{2}\right] \\
& \mathrm{K}=\text { konstanta } \\
& \mathrm{Y} \quad=\text { aktual measurement }
\end{aligned}
$$

Gambar 2. Grafik Fungsi Quadratic Loss Smaller the best.

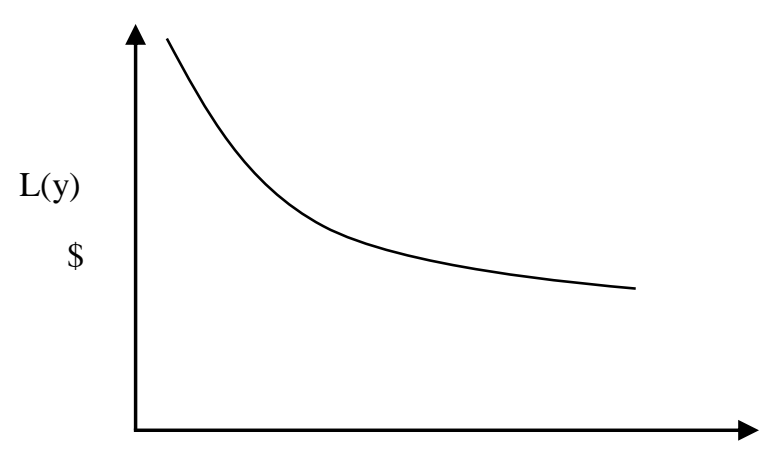

Untuk 1 produk:

$\mathrm{L}(\mathrm{y})=k\left(\frac{1}{y}\right)^{2}$

Untuk sample :

$$
\mathrm{L}(\mathrm{y})=\frac{k}{\mu^{2}}\left[1+\frac{3 \sigma^{2}}{\mu^{2}}\right]
$$

Gambar 3. Grafik Fungsi Quadratic Loss Larger the best.

\subsubsection{Orthogonal Array dan Linear Graph}

Manfaat utama dari orthogonal array adalah untuk menghubungkan faktor yang digunakan dalam investigasi. Untuk setiap level dalam satu faktor, semua level dari faktor lain terjadi dalam jumlah yang sama. Manfaat lain dari orthogonal array adalah efisiensi biaya. Walaupun diseimbangkan, desain dari orthogonal array tidak membutuhkan semua kombinasi dari faktor yang di tes. Sehingga matrix eksperimen dapat lebih kecil tanpa kehilangan informasi yang vital. Hasilnya eksperimen dapat dilakukan dengan biaya yang efektif. 


\subsubsection{Robustness}

1. Klasifikasi karakteristik kualitas menurut nilai targetnya:

\section{a. Larger the Better $(\mathrm{QC}=\mathrm{B})$}

Tujuan dari karakteristik Larger the Better adalah untuk mencapai nilai yang sebesar/setinggi mungkin.

$$
S / N(\eta)=-10 \log \left(\frac{1}{n} \sum_{j=1}^{n} \frac{1}{y_{i}^{2}}\right)
$$

\section{b. Smaller the Better $(\mathrm{QC}=\mathrm{S})$}

Tujuan dari karakteristik Smaller the Better adalah untuk mencapai nilai yang serendah / sekecil mungkin yaitu 0 .

$$
S / N(\eta)=-10 \log \left(\frac{1}{n} \sum_{j=1}^{n} y_{i}^{2}\right)
$$

\section{c. Nominal the Best $(\mathrm{QC}=\mathrm{N})$}

Tujuan dari karakteristik Nominal the Better adalah untuk mencapai nilai yang yang telah ditentukan atau dengan nilai yang spesifik.

$$
S / N(\eta)=-10 \log \sum\left(\frac{\left(y i-\overline{y^{2}}\right)}{n-1}\right)
$$

2. Klasifikasi parameter

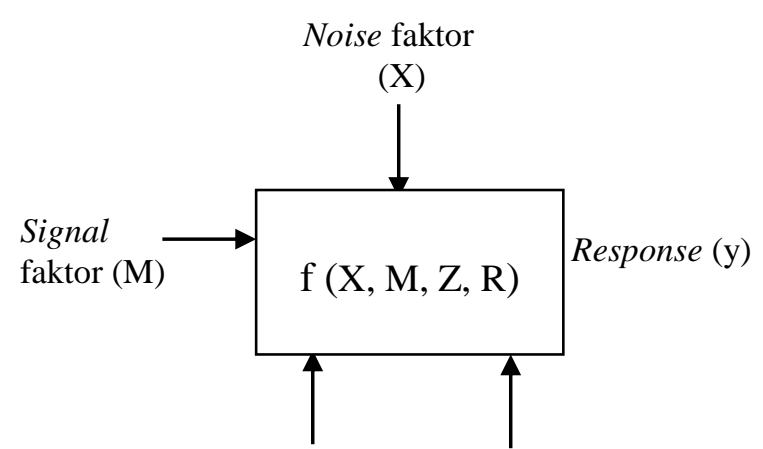

Control factor Scalling faktor (Z)

(R)

Gambar 4. Faktor Yang Mempengaruhi Karaketeristik Kualitas.

\subsubsection{Ekperimen}

Obyek untuk eksperimen adalah benda kerja kayu yang belum mencapai ketentuan standar nilai MC perusahan untuk produk jadi yaitu $\leq 18 \%$ pada kayu. Dilakukan 5 kali pengukuran dan diperoleh nilai MC kayu yang akan di jadikan benda objek yaitu $53 \%$, 50\%, 52\%, 53\% dan 51\% dengan mean $51.8 \%$. Langkah selanjutnya membuat kombinasi variabel dan level penelitian diperoleh kombinasi 9 benda obyek dengan dengan ukuran parameter seperti Tabel 1, berikut.

Tabel 1. Variabel Faktor Level

\begin{tabular}{|c|c|c|c|c|}
\hline $\begin{array}{c}\text { Benda } \\
\text { Objek }\end{array}$ & $\begin{array}{c}\text { Temp } \\
\left({ }^{0} \mathrm{C}\right)\end{array}$ & $\begin{array}{c}\text { Luas } \\
\text { penampang } \\
\text { Objek } \\
\left(\mathrm{Cm}^{2}\right)\end{array}$ & $\begin{array}{c}\text { Kelembaban } \\
\text { Udara } \\
\text { Relatif }(\%)\end{array}$ & $\begin{array}{c}\text { Waktu } \\
(\text { Hari })\end{array}$ \\
\hline 1 & 40 & 415 & 70 & 5 \\
2 & 40 & 325 & 80 & 10 \\
3 & 40 & 190 & 90 & 15 \\
4 & 50 & 415 & 80 & 15 \\
5 & 50 & 325 & 90 & 5 \\
6 & 50 & 190 & 70 & 10 \\
7 & 60 & 415 & 90 & 10 \\
8 & 60 & 325 & 70 & 15 \\
9 & 60 & 190 & 80 & 5 \\
\hline
\end{tabular}

Proses lanjutan adalah dengan pemotongan kayu dengan ukuran yang telah ditentukan sesuai kombinasi variabel dan level penelitian dengan ukuran berturut turut : $7 \mathrm{~cm} \times 20 \mathrm{~cm} \times 2.5 \mathrm{~cm} ; 5 \mathrm{~cm} \times 20 \mathrm{~cm}$ $\mathrm{x} 2.5 \mathrm{~cm}$ masing - masing 3 buah. Eksperimen dilakukan pada 3 chamber klin dryer. Penelitian dilakukan dengan jawadwal. Pada hari I, benda objek 1 di masukan pada chamber 1 dengan pengaturan parameter untuk temperature $40^{\circ} \mathrm{C}$ dan kelembaban udara relatif $70 \%$, Benda objek 5 di masukan pada chamber 2 dengan parameter untuk temperatur $50^{\circ} \mathrm{C}$ dan kelembaban udara relatif $90 \%$. Benda objek 9 di masukan pada chamber 3 dengan pengaturan parameter untuk temperatur $60^{\circ} \mathrm{C}$ dan kelembaban udara relatif $80 \%$. Pada hari ke- 6 benda objek 1, 5 dan 9 dikeluarkan dari chamber dan dilakukan pengukuran MC. Percobaan selanjutnya dilakukan pada obyek $2,6,7, ; 3,4,8$ dengan pengaturan 
parameter sesuai pada tabel 1 diatas dengan pengukuran MC masing - masing. Selanjutnya dilakukan pemilihan nilai MC terkecil (karakteristik kualitas smaller the better.

\subsection{Menentukan faktor terkontrol, Noise dan Level}

Faktor terkontrol yang dipilih adalah temperatur, luas penampang, kelembaban, dan waktu. Jumlah level adalah 3. Noise faktor atau faktor yang tidak terkontrol yang dipilih adalah pengukuran moisture content dari bidang kerja.Tabel 2 adalah Variabel faktor level.

Tabel 2. Variabel Faktor Level

\begin{tabular}{|ll|c|c|c|}
\hline \multicolumn{2}{|c|}{ Faktor Terkontro } & Level & Level & Level \\
& & 2 & 3 \\
\hline A. & Temperatur $\left({ }^{0} \mathrm{C}\right)$ & 40 & 50 & 60 \\
B. & $\begin{array}{l}\text { Luas } \\
\text { Penampang }\end{array}$ & 415 & 325 & 190 \\
& $\begin{array}{l}\text { Objek }\left(\mathrm{Cm}^{2}\right) \\
\text { Kelembaban }\end{array}$ & 70 & 80 & 90 \\
C. & $\begin{array}{l}\text { Udara Relatif } \\
(\%)\end{array}$ & & & \\
D. & Waktu (hari) & 5 & 10 & 15 \\
\hline
\end{tabular}

\subsection{Menentukan Orthogonal Array}

Orthogonal array sesuai $=$ DOFexp $\geq$ DOFtot; Jumlah faktor $=4$, Level $=3$, DOFtot $=4 \times(3-1)=8$, DOFexp $=\mathrm{N}$, exp 1 , DOFexp $\geq 8$, Nexp - $1 \geq 8$, Nexp $\geq 8+1$, dan Nexp $\geq 9$. Dengan demikian orthogonal array yang mungkin $\mathrm{L}_{9}\left(3^{4}\right)$; Untuk L9 $\left(3^{4}\right)$; dan $\mathrm{DOF}_{\text {tot }}=\mathrm{DOF}_{\text {exp }}$ sehingga seimbang. Efisiensi eksperimen $=$ DOFtot $/$ DOFexp $\mathrm{x}$ $100 \%=8 / 8 \times 100 \%=100 \%$

Tabel 3 Orthogonal Array (Belavendram, 1995)

\begin{tabular}{|c|c|c|c|c|}
\hline No eksp & 1(A) & $\mathbf{2 ( B )}$ & $\mathbf{3 ( C )}$ & $\mathbf{4 ( D )}$ \\
\hline 1 & 1 & 1 & 1 & 1 \\
2 & 1 & 2 & 2 & 2 \\
3 & 1 & 3 & 3 & 3 \\
4 & 2 & 1 & 2 & 3 \\
5 & 2 & 2 & 3 & 1 \\
6 & 2 & 3 & 1 & 2 \\
7 & 3 & 1 & 3 & 2 \\
8 & 3 & 2 & 1 & 3 \\
9 & 3 & 3 & 2 & 1 \\
\hline
\end{tabular}

\subsection{Menghitung Nilai MC (Faktor Noise)}

Pengukuran faktor noise pada penampang obyek (surface roughness) dilakukan sebanyak 3 kali seperti pada Tabel 4. Dengan rumus rata - rata respon $=\frac{1}{n} \sum_{j=1}^{n} y_{i}$, dan menghitung $\mathrm{S} / \mathrm{N}$ ratio seperti persamaan 2 .

Tabel 4. Nilai Surface Roughness dan Hasil Eksperimen

\begin{tabular}{|c|c|c|c|c|c|c|c|c|c|}
\hline \multirow[t]{2}{*}{ No.Eks } & \multirow[t]{2}{*}{ A } & \multirow[t]{2}{*}{ B } & \multirow[t]{2}{*}{ C } & \multirow[t]{2}{*}{ D } & \multicolumn{3}{|c|}{$\begin{array}{c}\text { Response } \\
\text { (MC) } \%\end{array}$} & \multirow{2}{*}{$\begin{array}{l}\text { Rata- } \\
\text { rata }\end{array}$} & \multirow{2}{*}{$\begin{array}{c}(\mathrm{dBi}) \\
\mathrm{S} / \mathrm{N} \\
\text { Value }\end{array}$} \\
\hline & & & & & 1 & 2 & 3 & & \\
\hline 1 & 1 & 1 & 1 & 1 & 28 & 26 & 26 & 26,6667 & $\begin{array}{c}- \\
28,5248\end{array}$ \\
\hline 2 & 1 & 2 & 2 & 2 & 22 & 24 & 22 & 22,6667 & 27,1153 \\
\hline 3 & 1 & 3 & 3 & 3 & 24 & 24 & 22 & 23,3333 & $\begin{array}{c}- \\
27,3666\end{array}$ \\
\hline 4 & 2 & 1 & 2 & 3 & 16 & 18 & 18 & 17,3333 & $\begin{array}{c}- \\
24,7905 \\
\end{array}$ \\
\hline 5 & 2 & 2 & 3 & 1 & 24 & 26 & 24 & 24,6667 & $\begin{array}{c}- \\
27,8485 \\
\end{array}$ \\
\hline 6 & 2 & 3 & 1 & 2 & 24 & 24 & 22 & 23,333 & $\begin{array}{c}- \\
27,3666 \\
\end{array}$ \\
\hline 7 & 3 & 1 & 3 & 2 & 22 & 22 & 22 & 22 & $\begin{array}{c}- \\
26,8485\end{array}$ \\
\hline 8 & 3 & 2 & 1 & 3 & 18 & 18 & 20 & 18,6667 & $\begin{array}{c}- \\
25,4324\end{array}$ \\
\hline 9 & 3 & 3 & 2 & 1 & 24 & 24 & 26 & 24,6667 & $\begin{array}{c}- \\
27,8485\end{array}$ \\
\hline
\end{tabular}

\subsection{Analisa Variance (ANOVA)}

Untuk mengetahui pengaruh faktor faktor kendali berdasarkan fungsi kualitas smaller the better, maka didapat persamaan:

$$
\mathrm{Y}_{\text {target }}=\mu+A_{\mathrm{i}}+\mathrm{B}_{\mathrm{j}}+\mathrm{C}_{\mathrm{k}}+\mathrm{D}_{\mathrm{l}}+\mathrm{e}
$$

$\mathrm{Y}_{\text {target }}=$ Moisture Content, Faktor $\mathrm{A}=$ Temperatur $\left({ }^{\circ} \mathrm{C}\right)$, Faktor $\mathrm{B}=$ Luas Penampang Objek $\left(\mathrm{cm}^{2}\right)$, Faktor $\mathrm{C}=$ Kelembaban Udara Relatif (\%) dan Faktor D $=$ Waktu (hari).

\subsection{Hipotesis}

Faktor A (Temperatur) Ho = Tidak ada pengaruh yang signifikan antara temperatur dengan hasil moisture content. Dan H1= Ada pengaruh yang signifikan antara temperatur dengan hasil moisture content.Faktor $B$ (Luas Penampang Objek) 
Ho $=$ Tidak ada pengaruh yang signifikan antara luas penampang objek dengan hasil moisture content. $\mathrm{H} 1$ = Ada pengaruh yang signifikan antara luas penampang obyek dengan hasil moisture content. Faktor $C$ (Kelembaban Udara Relatif). Ho = Tidak ada pengaruh yang signifikan antara kelembaban udara relatif dengan hasil moisture content. $\mathrm{H} 1$ = Ada pengaruh yang signifikan antara kelembaban udara relatif dengan hasil moisture content. Faktor D (Waktu) $\mathrm{Ho}=$ Tidak ada pengaruh yang signifikan antara waktu dengan hasil moisture content. $\mathrm{H} 1$ = Ada pengaruh yang signifikan antara waktu dengan hasil moisture content. Tingkat signifikansi : $\alpha=$ 0,05; dimana Ftabel $=\mathrm{F}_{0.05, \mathrm{v} 1, \mathrm{v} 2}=\mathrm{F}_{0.05,2,18}=$ 3,55; Kriteria pengujian, yaitu: Ho diterima apabila $F_{\text {hitung }} \leq \mathrm{F}_{\text {tabel; }}$; Ho ditolak apabila : $F$ hitung $>\mathrm{F}_{\text {tabel.. }}$ Dibawah ini adalah Tabel 5 Anova yang diperoleh dalam ekperimen yang dilakukan.

Tabel 5. Anova

\begin{tabular}{|c|c|c|c|c|c|c|}
\hline Sumber & SS & $\mathbf{v}$ & Mq & $\begin{array}{c}\mathbf{F} \\
\text { ratio }\end{array}$ & $\begin{array}{c}\text { F. } \\
\text { Tabel }\end{array}$ & $\mathbf{S S}^{1}$ \\
\hline A & $\begin{array}{l}35 \\
85\end{array}$ & 2 & 17,93 & $\begin{array}{c}15,13 . \\
8,00.6 \\
, 50\end{array}$ & 3,55 & $\begin{array}{l}33 \\
48\end{array}$ \\
\hline B & $\begin{array}{l}18 \\
96\end{array}$ & 2 & 9,48 & 58,63 & 3,55 & $\begin{array}{l}16 \\
59\end{array}$ \\
\hline $\mathrm{C}$ & $\begin{array}{l}15 \\
41\end{array}$ & 2 & 7,70 & 1 & 3,55 & $\begin{array}{l}13 \\
04\end{array}$ \\
\hline $\mathrm{D}$ & $\begin{array}{c}138 \\
, 96\end{array}$ & 2 & 69,48 & & 3,55 & $\begin{array}{l}136 \\
, 59\end{array}$ \\
\hline e & $\begin{array}{l}21 \\
33\end{array}$ & 18 & 1,19 & & & $\begin{array}{l}30 \\
81\end{array}$ \\
\hline $\mathrm{St}$ & $\begin{array}{r}230 \\
, 52 \\
\end{array}$ & 26 & 8,87 & & & $\begin{array}{r}230 \\
, 52 \\
\end{array}$ \\
\hline
\end{tabular}

Analisa ANOVA menyatakan bahwa $\mathrm{F}$ ratio untuk semua faktor, yaitu : $\mathrm{F}_{\text {hitung }}>$ $\mathrm{F}_{\text {tabel, }}$ maka Ho ditolak artinya ada pengaruh yang signifikan antara faktor dengan raw data. Berdasar dari kontribusi sumber (faktor) mulai dari yang terbesar $\mathrm{D}=$ $59.25 \%$; faktor $\mathrm{A}=14.52 \%, \mathrm{~B}=7.20 \%$; $\mathrm{C}$ $=5.66 \%$ dan error $=13.37 \%$. Sehingga pengambilan data tidak bias.

\subsection{Analisa Average Effect Response Mean dan S/N Ratio}

Analisa rata - rata respon terhada $\mathrm{S} / \mathrm{N}$ ratio dapat dilihat pada Tabel 6 dibawah ini:

Tabel 6. Average Effect Response Untuk S/N Ratio

\begin{tabular}{|c|c|c|c|c|}
\hline Level & Temp & Luas P & Kelemb & Waktu \\
\hline 1 & $-27,6689$ & $-26,7212$ & $-27,1079$ & $-28,0740$ \\
2 & $-26,6685$ & $-26,7987$ & $-26,5848$ & $-27,1101$ \\
3 & $-26,7098$ & - & $-27,3545$ & $-25,8632$ \\
& & $27,5273-$ & & \\
Delta & 1,00035 & 0,80602 & 0,76978 & 2,21080 \\
Rank & $\mathbf{2}$ & $\mathbf{3}$ & $\mathbf{4}$ & $\mathbf{1}$ \\
\hline
\end{tabular}

Tabel 7. Average Effect Response Mean

\begin{tabular}{|c|c|c|c|c|}
\hline Level & Temp & Luas P & Kelemb & Waktu \\
\hline 1 & 24,2222 & 22,0000 & 22,8889 & 25,3333 \\
2 & 21,7778 & 22,0000 & 21,5556 & 22,6667 \\
3 & 21,7778 & 23,7778 & 23,3333 & 19,7778 \\
Delta & 2,44444 & 1,77778 & 1,77778 & 5,55556 \\
Rank & $\mathbf{2}$ & $\mathbf{3}$ & $\mathbf{4}$ & $\mathbf{1}$ \\
\hline
\end{tabular}

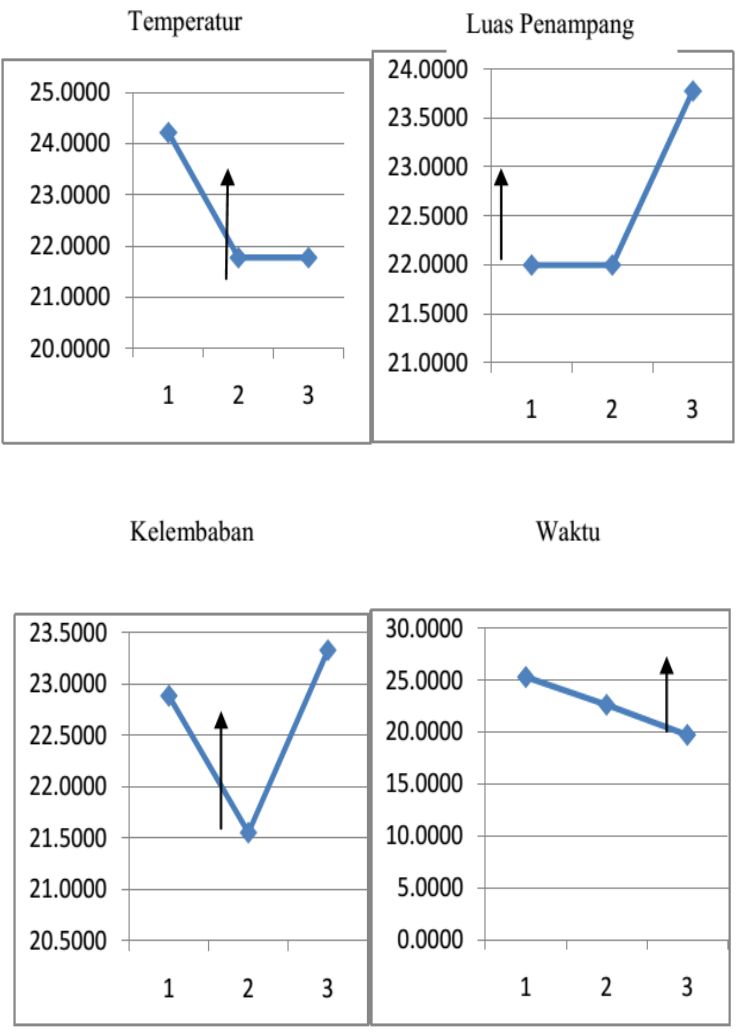

Gambar 5 Grafik main effect plot for mean. 

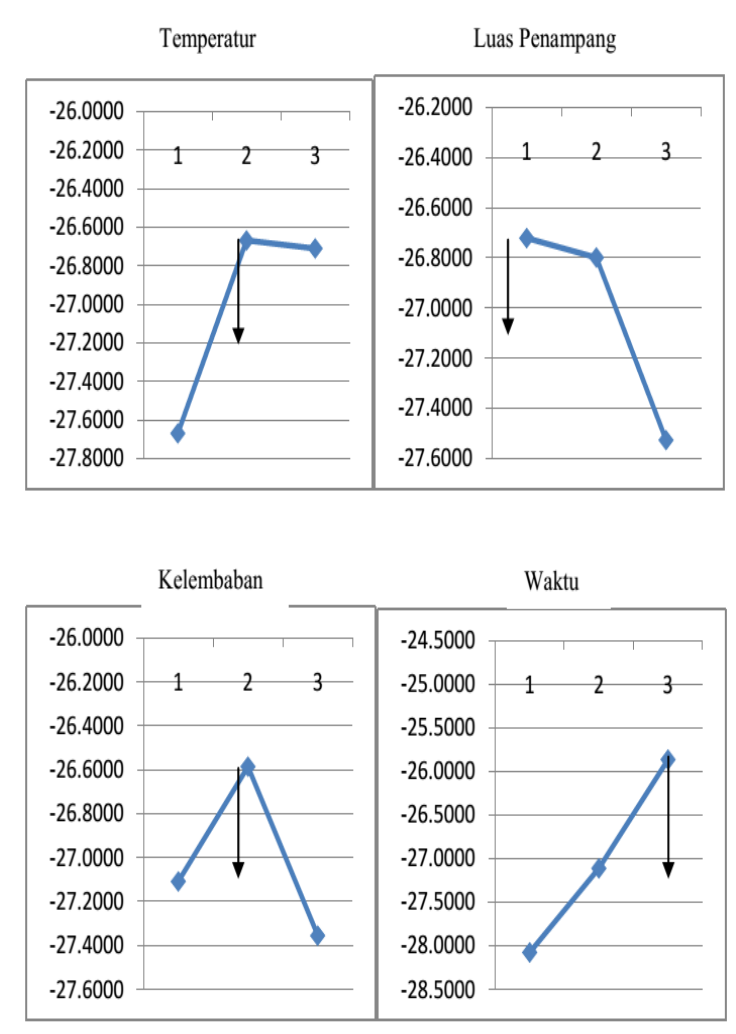

Gambar 6 Grafik main effect plot for $S / N$ ratio.

\subsection{Menentukan Kombinasi Faktor-Level Optimum}

Table 4.9 Faktor, level and Pengaruhnya

\begin{tabular}{|l|c|c|c|}
\hline \multicolumn{1}{|c|}{ Faktor } & level & $\begin{array}{c}\text { Av. Effect } \\
\text { Response } \\
\text { Mean }\end{array}$ & $\begin{array}{l}\text { Av.Effect } \\
\text { Response } \\
\text { S/N Ratio }\end{array}$ \\
\hline $\begin{array}{l}\text { Depth cut } \\
\text { (A) }\end{array}$ & 2 & 21,7778 & $-26,6685$ \\
$\begin{array}{l}\text { Spindle } \\
\text { speed (B) } \\
\text { Feed Rate } \\
\text { (C) }\end{array}$ & 1 & 22 & $-26,7212$ \\
$\begin{array}{l}\text { Tool } \\
\text { Diameter } \\
\text { (D) }\end{array}$ & 3 & 19,7778 & $=25,8632$ \\
\hline
\end{tabular}

Menentukan kombinasi faktor level optimum, sehingga faktor level yang optimum didapat pada Temperatur (A2) = $50^{\circ} \mathrm{C}$, Luas penampang objek (B1) $=415$ $\mathrm{cm}^{2}$. Kelembaban udara relatif $(\mathrm{C} 2)=80 \%$, Waktu (D3) $=15$ hari. Tabel 8 adalah faktor level dan pengaruhnya.

\subsection{Memprediksi MC Optimum}

Predicted mean dihitung berdasarkan rumus sebagi berikut:

$$
\begin{aligned}
& \text { Predicted } \\
& \overline{A_{i}}+\overline{B_{j}}+\overline{C_{k}}+\overline{D_{l}}-3 X(\bar{Y}) \\
& =\overline{A_{2}}+\overline{B_{1}}+\overline{C_{2}}+\overline{D_{3}}-3 X(\bar{Y})== \\
& 21.7778+22+21.5556+19.7778-3 \times \\
& 22.5926 \quad=\quad 17.3334 \\
& \text { Predicted S/N }=\bar{\eta}_{A 2}+\bar{\eta}_{B 1}+\bar{\eta}_{C 2}+\bar{\eta}_{D 3}-3 \sum \bar{\eta} \\
& =-26.6685-26.7212-26.5848- \\
& 25.8632-3 \times(-27.0157)=-24.7906 .
\end{aligned}
$$

Berdasarkan penghitungan hasil prediksi diatas maka hasil moisture contentoptimum yang dapat dicapai yaitu $17.3334 \%$ dengan nilai variasi -24.7906 .

\subsection{Confirm eksperimen}

a. Eksperimen konfirmasi dilakukan sebanyak 5 kali. Hasil yang diperoleh yaitu 18, 17, 17, 20 dan 17. Dengan mean 17.8 .

b. Confidence interval-predicting mean

$$
C I=\sqrt{F_{a_{2} v 1, v 2}} x V_{e x}\left[\frac{1}{n_{e f f}}\right]
$$

Dengan

$\mathrm{n}_{\text {eff }}=\frac{\text { jumlah eksperimen }}{\text { Sum } 0 \text { of Degree of Freedom Used In Estimate of Mean }}$

$=\frac{9 \times 3}{2+2+2+2}=3.375 \mathrm{CI}=$

$\sqrt{F_{a, 2,18}} \times V 1,185_{e x}\left[\frac{1}{3,375}\right]=1,1644$

$\mu_{\text {predicted }}-C I \leq \mu_{\text {predicted }} \leq \mu_{\text {predicted }}+C I$

$17,3334 \quad-\quad \ldots 1,1644$

$\leq \mu_{\text {predicted }} \leq 17,3334+1,164416,169$

$\leq \mu_{\text {predicted }} \leq 18,4978$ 
c. Confidence interval-confirm mean CI=

$\sqrt{F_{a_{a} v 1, v 2}} x V_{\theta x x}\left[\frac{1}{n_{e f f}}+\frac{1}{r}\right]=$

$\sqrt{F_{a_{n} 2,18}} x V 1,185_{\operatorname{ex}}\left[\frac{1}{3,375}+\frac{1}{5}\right]=1,4445$

$\mu_{\text {confirmation }}-C I \leq \mu_{\text {confirmation }} \leq \mu_{\text {con }}$

$17,8-1,4445 \leq \mu_{\text {confirmation }} \leq 17,8+1$,

$16,3555 \leq \mu_{\text {confirmation }} \leq 19,2445$

d. Membandingkan Confidence intervalpredicting mean dengan Confidence interval-konfirmasi mean Confidence

interval predicting mean 16,169

$\leq \mu_{\text {predicted }} \leq 18,4978$ Confidence

interval confirm mean 16,3555

$\leq \mu_{\text {predicted }} \leq 19,2445$.

e. Menghitung loss per piece Dari penghitungan $\mu$ optimum $=-15,5289$. Sedangkan $\mu$ existing dengan kombinasi faktor -level A1, B1, C1 dan D1 diperoleh $-24,6207$.

$$
\begin{aligned}
\varphi & =k M S D_{\text {existing }} x\left[1-0.5^{\left(\frac{\mu_{\text {predicted }}-\mu_{\text {existing }}}{s}\right)}\right] \\
\varphi & =k M S D_{\text {existing }} x\left[1-0.5^{(1,2447)}\right] \\
& =k M S D_{\text {existing }} x n 0,578
\end{aligned}
$$

f. Menghitung perubahan biaya

Dari perhitungan didapat nilai $\mathrm{t}$ (variabel waktu) optimum $=360$ jam, sedangkan $\mathrm{t}$ exsisting $=120$ jam. Maka di dapat perubahan biaya sebagai berikut :

$\mathrm{C} 1=\mathrm{k} . \mathrm{t} 1=4000 \times 120=480000$ dan $\mathrm{C} 2=$ $\mathrm{kt} 2=4000 \times 360=1440000$

Perubahan biaya $=\frac{c_{2}}{c_{1}} \times 100 \%=$ $\frac{1440000}{480000} \times 100 \%=300 \%$

\section{HASIL DAN PEMBAHASAN}

\subsection{Analisa Penentuan Faktor Terkontrol, Noise Faktor dan Level}

Nilai temperatur yang dipilih adalah 40 , 50 dan $60^{\circ} \mathrm{C}$ karena untuk mendapat hasil MGrayangtbaik temperature berkisar $40{ }^{\circ} \mathrm{C}-$ $60{ }^{\circ} \mathrm{C}$, karena bila kondisi disekitar kayu 4 terfalu jauh berbeda dengan kondisi dalam kayu, akan timbul ketegangan dalam kayu (drying stresses). Ukuran luas penampang yang dipilih yaitu 415, 235 dan $190 \mathrm{~cm}^{2}$. Karena ukuran kayu yang di peroleh dari limbah industri lain maupun sisa dari pemotonga kayu log yaitu $5 \mathrm{~cm}-10 \mathrm{~cm}$ untuk lebar dan dengan ketebalan $1 \mathrm{~cm}-3$ $\mathrm{cm}$. Terkait dengan peningkatannya produksi kayu olahan. Nilai kelembaban udara relatif yang dipilih yaitu 70,80 dan $90 \% / \mathrm{m}^{3}$. Untuk mendapatkan nilai moisture content $\leq 20 \%$ maka nilai kelembaban udara relatif harus $\leq$ $90 \% / \mathrm{m}^{3}$, tetapi sama seperti temperatur, kelembaban udara relatif yang dikenakan tidak boleh terlalu rendah karena dapat menyebabkan drying stresses. Untuk proses pengeringan dilakukan dalam 3 chamber kiln dryer dan dengan 3 pengelompokan periode yaitu 5, 10 dan 15 hari. Ukuran periode ini di sesuaikan dengan jadwal pengeringan kayu yaitu $10-20$ hari.

\subsection{Analisa Orthogonal Array}

Dalam penelitian ini digunakan empat faktor dengan tiga level tanpa adanya interaksi antar faktor. Dari penghitungan kesesuaian orthogonal array didapat bahwa orthogonal array yang sesuai adalah $\mathrm{L}_{9}\left(3^{4}\right)$. Orthogonal array $\mathrm{L}_{9}\left(3^{4}\right)$ terdiri dari empat kolom yang masing - masing kolom terdiri dari tiga level, sehingga setiap kolom dari orthogonal array tersebut digunakan sebagai kombinasi eksperimen. Dari penghitungan nilai efisiensi eksperimen penelitian ini didapat nilai sebesar $100 \%$, artinya pemakaian orthogonal array ini sangat efisien diterapkan dalan eksperimen ini. 


\subsection{Analisa Nilai MC}

Untuk menentukan nilai MC digunakan Lignomat Wood Moisture meter. Dilakukan dengan 3 kali pengukuran agar diperoleh nilai yang lebih akurat.

\subsection{Analisa dari ANOVA}

Uji ANOVA digunakan untuk mengetahui pengaruh dari masing - masing faktor terhadap data. Dengan uji ini juga dapat diketahui seberapa besar error dalam pengambilan data. Derajat bebas denumerator didapat dari banyak level - 1 , yaitu $3-1=2$. Untuk derajat bebas numerator didapat dari $27-1-8=18$. Dengan tingkat signifikansi 0.05 maka diperoleh $F_{\text {tabel }}$ sebesar 3.55. Analisa nilai $F$ ratio dari setiap faktor adalah sebagai berikut: $\mathrm{F}$ ratio temperatur adalah $15.13>$ 3.55 , artinya temperatur mempengaruhi secara signifikan terhadap raw data. F luas penampang objek adalah $8>3.55$ artinya luas penampang obyek mempengaruhi secara signifikan terhadap raw data. $\mathrm{F}$ ratio kelembaban udara relatif adalah $6.5>3.55$ artinya kelembaban udara relatif mempengaruhi secara signifikan terhadap raw data. F waktu diameter adalah $58.63>$ 3.55 artinya waktu mempengaruhi secara signifikan terhadap raw data. Analisa kontribusi setiap faktor terhadap raw data. Berdasarkan nilai $\mathrm{F}$ ratio, faktor luas penampang obyek faktor kelembaban udara relatif mempengaruhi secara signifikan raw data tetapi memberi kontribusi yang sangat kecil yaitu sebesar 7.2\% dan 5.66. Hal ini dimungkinkan kondisi tool yang digunakan dalam kondisi yang tidak sama. Error memberikan kontribusi sebesar $13.37 \%$ dan melebihi faktor luas penampang obyek faktor kelembaban udara relatif sehingga pengambilan data bias. Hal ini mungkin dikarenakan oleh seting parameter untuk faktor luas penampang obyek faktor kelembaban udara relative tidak dapat mewakili identitas dari masing - masing faktor tersebut.
Analisa Average Effect Response Mean dan S/N Ratio. Average effect response mean digunakan untuk mengetahui performa dari masing - masing faktor dan level. Performa terbaik adalah faktor level yang mempunyai nilai average effect response mean terkecil. Nilai delta dari masing - masing faktor dapat juga digunakan untuk mengetahui urutan kontribusi masing - masing faktor terhadap raw data. Dari nilai delta tersebut diperoleh urutan faktor dari yang terbesar adalah: waktu, temperatur, luas penampang objek dan kelembaban udara relatif. Hasil ini sama dengan hasil dari uji ANOVA. Untuk mempermudah dalam analisa maka digunakan plot data:

Untuk temperatur optimal didapat pada level 2. Performa paling rendah didapat pada level 1. sedangkan luas penampang objek, level optimal didapat pada level 1. Apabila level dinaikkan maka performa semakin rendah. Sedangkan kelembaban udara relatif optimal didapat pada level 2. Performa paling rendah dicapai pada level 3 . Selanjutnya waktu optimal didapat pada level 3. Apabila level diturunkan maka performa semakin rendah. Performa terendah pada level 1. Dalam plot data digambarkan dengan adanya tanda panah keatas, berarti jika nilai mean semakin kecil maka performa justru semakin baik.

Average Effect $\mathrm{S} / \mathrm{N}$ Ratio digunakan untuk mengetahui variasi dari masing masing faktor dan level. Variasi terkecil adalah faktor level yang yang mempunyai nilai Average Effect $\mathrm{S} / \mathrm{N}$ Ratio terbesar. Nilai delta juga digunakan untuk mengetahui urutan kontribusi faktor terhadap raw data. Dari nilai delta tersebut diperoleh urutan faktor dari yang terbesar adalah feed rate, depth cut, spindle speed dan tool diameter. Hasil ini sama dengan hasil dari analisa average effect response mean dan uji ANOVA. 
Untuk temperatur, nilai $\mathrm{S} / \mathrm{N}$ terbaik diperoleh pada level 2. Level 1 menghasilkan variasi yang paling besar. Dari level 2 ke 3 maka menghasilkan variasi yang lebih kecil. Untuk luas penampang obyek, nilai S/N terbaik diperoleh pada level 1. Apabila level dinaikkan maka variasi semakin besar. Kelembaban udara relatif, nilai S/N terbaik diperoleh pada level 2. Level 1 menghasilkan variasi yang paling besar. Dari level 2 ke 3 maka menghasilkan variasi yang lebih kecil.

Untuk waktu, nilai $\mathrm{S} / \mathrm{N}$ terbaik diperoleh pada level 3. Apabila level diturunkan maka ariasi semakin besar. Dalam plot data digambarkan dengan adanya tanda panah kebawah, berarti jika nilai mean semakin besar maka variasi justru semakin baik. Sehingga faktor level yang optimum didapat pada Temperatur $(\mathrm{A} 2)=50{ }^{\circ} \mathrm{C}$, Luas Penampang Obyek (B1) $=415 \mathrm{~cm}^{2}$, Kelembaban Udara Relatif $(\mathrm{C} 2)=80 \%$, Waktu (D3) $=15$ hari. Dari penghitungan nilai rata - rata prediksi diperoleh sebesar 17.33 dan prediksi S/N ratio -24.7906. Jika dibanding dengan nilai rata - rata eksperimen, nilai rata - rata prediksi lebih kecil artinya nilai prediksi mempunyai performansi yang lebih baik. Dan nilai prediksi S/N ratio lebih besar daripada nilai $\mathrm{S} / \mathrm{N}$ ratio eksperimen artinya variasinya lebih baik. Analisa eksperimen konfirmasi dilakukan sebanyak 5 kali. Hasil yang diperoleh adalah 18, 17, 17, 20 dan 17. Dengan mean 17.8. Untuk mengetahui, hasil dari predicting mean reproducible yaitu dengan membandingkan nilai Confidence interval-predicting mean dengan Confidence interval-konfirmasi mean. Jika confidence intervall - predicting mean lebih besar dari confidence interval - konfirmasi mean maka predicting mean reproducible. Dari penghitungan diperoleh confidence intervalrata - rata prediski $16.169 \leq \mu_{\text {predicted }} \leq 18.4978$ Confidence rata - rata interval - konfirmasi $16.3555 \leq \mu_{\text {predicted }} \leq 19.2445$. Nilai bawah rata - rata prediksi confidence interval lebih kecil dari rata - rata confidence interval - konfirmasi yaitu $16.169<16.3555$. Nilai atas confidence rata - rata intervall predicting lebih kecil dari rata - rata confidence interval-konfirmasi yaitu 18.4978 $>$ 19.2445. Sehingga tidak reproducible. Analisa Loss per Piece diperoleh hasil $\wp=k M S D_{\text {existing }} x 0.57$. Artinya adanya peningkatan performansi atau penurunan loss sebesar $0.57 \%$ dibandingkan dengan sebelumnya dan terjadi peribahan biaya sebesar $300 \%$ lebih murah.

\section{KESIMPULAN DAN SARAN}

\subsection{Kesimpulan}

Kesimpulan yang diberikan pada penelitian ini adalah Nilai moisture content yang optimal adalah sebesar $17.3334 \%$. level yang optimum didapat pada Temperatur $(\mathrm{A} 2)=50{ }^{\circ} \mathrm{C}$, Luas Penampang Obyek $(\mathrm{B} 1)=415 \mathrm{~cm}^{2}$, Kelembaban Udara Relatif $(C 2)=80 \%$, Waktu (D3) $=15$ hari. Selanjutnya, kontribusi setiap faktor terhadap hasil surface roughness, yaitu: faktor waktu $=59.25 \%$, faktor temperatur $=$ $14.52 \%$, faktor luas penampang obyek = $7.20 \%$,dan faktor kelembaban udara relatif $=5.66 \%$. Sehingga dicapai peningkatan performa atau penurunan loss sebesar $0.57 \%$ dibanding dengan pengaturan sebelumnya.

\subsection{Saran}

Selanjutnya untuk lebih menyempurnakan hasil penelitian awal ini perlu dilakukan penelitian dengan memasukkan faktor lain dan respon yang lebih komplek. 


\section{DAFTAR PUSATAKA}

Belavendram, N., 1995, Quality By Design Taguchi Techniques for Industrial Experimentation, Prentice-Hall International, Maylands Avenue, UK

Dumanauw, J. F., 1993. Mengenal Кауи, Penerbit Kanisius, Semarang.

Fowlkes, Y. W and Creveling, M. C. 1995. Engineering methods for robust product design: Using Taguchi Methods in Technology and Product Development. AddisonWesley,

Lin, S.C., 1994, Computer Numerical Control-From Programming To Networking, Albany, New York, Delmar

Sumarno, Muhammad Agung., 2007, Optimasi Surface Roughness pada Operasi End Milling, Jurusan Teknik Industri, Fakultas Teknologi Industri, Yogyakarta. Tidak dipublikasikan

Vairis, A. dan Petousis, M., 2009, Designing experiments to study welding processes: using the Taguchi method, Mechanical Engineering Dept. TEI of Crete, Heraklion 71004, Greece.

Rhodes, Daniel, 1968. Kilns; Design, Construction, And Operation, Philadelphia, Chilton Book Co. [1968] viii, hal 240.

William T. Simpson, 1991. Dry Kiln Operator's Manual, Edited by, Research Forest Products Technologist, United States Department of Agriculture, Forest Service, Forest Products Laboratory, Madison, Wisconsin, Revised August, Agriculture Handbook 188. 